\title{
Building Information Modelling (BIM) Initiatives for Malaysian Construction Industry
}

\author{
${ }^{* 1}$ Mashanim Mahazir, Puah Kar Ros \\ ${ }^{1}$ Centre of Building and Resilient Development (CeBRD) \\ Faculty of Engineering, Built Environment \& IT, SEGi University \\ *mashanim@segi.edu.my
}

\begin{abstract}
The construction industry believes that Building Information Modelling (BIM) are able to reduce the problem faced by the infrastructure world. Nowadays, the construction industry faced many problems due to dependency on the traditional practice. Therefore, the application of BIM in the construction industry will help the construction projects become more successful. Fourteen (14) papers were referred through extensive literature review and the study aims to discuss the benefits and barriers of using BIM in the construction industry. Furthermore, the strategic planning being implemented the BIM within the next 5 years in Malaysia also been discussed.
\end{abstract}

Keywords: Implementation, Building Information Modelling, Construction industry

\section{Introduction}

According to Takim, R., Harris, M., \& Nawawi, A. H., (2013) due to the increasing budgets, technological uncertainty and development process, the construction industry environment is becoming more competitive. As Malaysia gradually moves toward industrialization, the construction industry in Malaysia has been developed from the craft-based industry, low technology and intensive labour to one that was able to transfer the infrastructure and advanced building, using innovation of mechanizes production techniques. 
According to Tahir et al. (2017), BIM is defined as a set of interacting processes, policies and technologies that generate a way to manage project data in digital format and building layout throughout the building's life cycle. Therefore, BIM implementation is a useful alternative way to deal with the key to construction problems to increase efficiency, productivity, quality, lead times, duplication and effective communication with the employer in remote construction industry projects. The BIM application has grown up staggeringly, from a tool to a three-dimension design, from a tool that can be used to evaluate the model, product selection, the entire project conceptualization and detect the conflicts. Thus, the introduction of BIM should prevent construction conflicts arising from the poor conception of the project information. The construction industry is made up of different parties from diverse professions that administrate with their own rules. The integrative application of BIM for the life-cycle of the building is seen as able to interact with the disjointed parties. This is due to the private and public sectors are experiencing the complexities, arguments, and ambiguities with the traditional ways that use in the construction industry. During the opening of Infrastructure \& Construction Asia's Building Information Modelling and Sustainable Architecture Conference, Malaysia has begun to adopt BIM technology with the idea of maximizing the investment value throughout the various plans and utilizing the different ICT solutions in its strategies. The government has adopted BIM with the first infrastructure project which is the National Cancer Institute in Sepang. According to Musa, S., Marshall-Ponting, A., Nifa, F. A. A., \& Shahron, S. A., (2018), from the expected completion actual date, this project was completed three weeks earlier. Hence, it was shown that the effective use of BIM that could resolve the problem at the beginning stage of construction life-cycle and shorten the construction period. Hence, BIM is believed to be a solution to many important problems such as low productivity, insufficient drawing, and specification, late design drawing by consultants, time and cost overrun which are embedded in the change order and instability in the construction sector.

\section{Methodology}


Fourteen (14) papers were referred in writing extensive literature review. The analyses of findings are tabulated into table. The papers covered the benefits of implementing the BIM, challenges in implementing the BIM and will discuss the strategic planning in implementing BIM.

\section{Result and discussion}

In this chapter, the benefit of adopting Building Information Modelling will be discussed. Moreover, it is also discussing the challenges and barriers when not using BIM in the construction industry. Lastly, this chapter also being carried out through 4-step of processes which include international benchmarking that reviews the strategic planning of BIM initiatives from the United Kingdom, Hong Kong, Singapore, and Australia. Following the engagement with stakeholders and experts of BIM through a structured interview and set of workshops. Such processes are then prioritized using the Impact (Imp) and Ease of Implementation (EOI) prioritizing software as the predetermining variables. In the end, the high EOI and Imp score will present than having a final selection and validation by the Focus Group.

\section{A. The Benefits of implementation of the BIM}

Based on the research report by Abulifa, A. A., Ahmad, R. K., Soh, A. C., Radzi, M. A., \& Hassan, M. K. (2017), government encourages the construction players to implement BIM in the projects because it can solve problem of construction such as clash of design failure, cost overrun, happen of accidents, delay of work and conflict among the construction players. Therefore, the BIM in construction can bring a lot of benefits as it can improve the quality of the projects. Based on the benefits discussed by Ahmad Latiffi, A., Mohd, S., \& Brahim, J. (2014), it is clear that BIM is useful to help the construction industry to construct either high-risk or small projects successfully. Hence, it can be concluded that BIM has the potential to be expanded and adapted in the construction field or engineering filed for future use. The benefits were depicted in Table 1 .

Table 1. The benefits of using BIM 


\begin{tabular}{|c|c|c|}
\hline NO & The Benefits of using BIM in the Construction Industry & Authors \\
\hline 1. & $\begin{array}{l}\text { BIM gives the right platform to assist the architect to initiate the } \\
\text { evolutionary design process. }\end{array}$ & $\begin{array}{l}\text { (Aryani Ahmad } \\
\text { Latiffi, Et Al. } \\
\text { 2013) }\end{array}$ \\
\hline 2. & $\begin{array}{l}\text { BIM can produce some of the data including the quantities of } \\
\text { materials automatically }\end{array}$ & $\begin{array}{l}\text { (Daniel W.M. } \\
\text { CHAN, 2019) }\end{array}$ \\
\hline 3. & $\begin{array}{l}\text { The BIM system can detect the internal conflict such as the } \\
\text { model viewing system that can highlight and detect the disputes } \\
\text { among the models. }\end{array}$ & (Leed, 2017) \\
\hline 4. & $\begin{array}{l}\text { BIM able to improve resource management and reduce the } \\
\text { environmental impact across the value chain. }\end{array}$ & $\begin{array}{l}\text { (Timothy O. } \\
\text { Olawumi, 2018) }\end{array}$ \\
\hline 5. & $\begin{array}{l}\text { BIM software has built-in cost estimating features. For example, } \\
\text { the material quantities are updated when any changes are made } \\
\text { in the model. }\end{array}$ & $\begin{array}{l}\text { (Salman Azhar, } \\
\text { 2011) }\end{array}$ \\
\hline 6. & $\begin{array}{l}\text { Able to reduce and prevent the materials from wastage through } \\
\text { reuse \& recycling and ensure materials efficiency. }\end{array}$ & $\begin{array}{l}\text { (Olugbenga } \mathrm{O} . \\
\text { Akinade, 2017) }\end{array}$ \\
\hline 7. & $\begin{array}{l}\text { The design speed can be improved by using the database } \\
\text { provided by BIM tools and communication with engineers is } \\
\text { less required. }\end{array}$ & $\begin{array}{l}\text { (Giles Thomas, } \\
\text { 2019) }\end{array}$ \\
\hline 8. & $\begin{array}{l}\text { Improving innovation capabilities and encourage the use of new } \\
\text { construction methods. }\end{array}$ & $\begin{array}{l}\text { (Timothy O. } \\
\text { Olawumi, 2018) }\end{array}$ \\
\hline 9. & Reduce site congestion and improve health and safety & $\begin{array}{l}\text { (Emlyn Witt, } \\
\text { 2019) }\end{array}$ \\
\hline 10. & $\begin{array}{l}\text { BIM assists the delivery of a construction project on or before } \\
\text { the schedule. }\end{array}$ & $\begin{array}{l}\text { (Daniel W.M. } \\
\text { CHAN, 2019) }\end{array}$ \\
\hline
\end{tabular}

Table 2. Analysis by multiple authors about the benefits of BIM 


\begin{tabular}{|c|c|c|c|c|c|}
\hline BENEFITS & $\begin{array}{l}\text { Reducing } \\
\text { the cost }\end{array}$ & $\begin{array}{l}\text { Reducing the } \\
\text { construction } \\
\text { time }\end{array}$ & $\begin{array}{l}\text { Assisting to } \\
\text { identify the } \\
\text { construction } \\
\text { issue and } \\
\text { problem }\end{array}$ & $\begin{array}{l}\text { Improving the } \\
\text { design process }\end{array}$ & $\begin{array}{c}\text { Able to } \\
\text { enhance the } \\
\text { communication } \\
\text { between the } \\
\text { construction } \\
\text { players }\end{array}$ \\
\hline $\begin{array}{l}\text { M.M.Tahir, } \\
\text { Haron,Et Al } \\
\text { (2018) }\end{array}$ & $x$ & $\mathrm{x}$ & & & \\
\hline $\begin{array}{l}\text { Suzila Mohd, Et } \\
\mathrm{Al}(2013)\end{array}$ & $\mathbf{x}$ & $\mathbf{x}$ & $\mathbf{x}$ & $\mathbf{x}$ & $\mathbf{x}$ \\
\hline $\begin{array}{l}\text { Aryani Ahmad } \\
\text { Latiffi,Et Al } \\
\text { (2014) }\end{array}$ & $\mathbf{x}$ & $\mathbf{x}$ & $\mathbf{x}$ & $\mathbf{x}$ & $\mathbf{x}$ \\
\hline $\begin{array}{l}\text { Aref Charehzehi, } \\
\text { ChangSaar Chai, } \\
\text { Et Al(2017) }\end{array}$ & & & $\mathbf{x}$ & & \\
\hline $\begin{array}{l}\text { Simen Birkeland } \\
\text { Aass (2015) }\end{array}$ & $\mathbf{x}$ & & & & \\
\hline $\begin{array}{l}\text { Poljansek Martin } \\
\text { (2017) }\end{array}$ & & & & $\mathbf{x}$ & \\
\hline $\begin{array}{l}\text { Sunil, K, } \\
\text { Pathirage, Et Al } \\
(2017)\end{array}$ & $\mathbf{x}$ & & & & \\
\hline $\begin{array}{l}\text { Mohd Harris, Et } \\
\mathrm{Al}(2014)\end{array}$ & $\mathrm{x}$ & $\mathbf{x}$ & $\mathbf{x}$ & & $\mathrm{x}$ \\
\hline $\begin{array}{l}\text { Fatin Afiqah } \\
\text { Ahmad Bajuri } \\
\text { (2017) }\end{array}$ & $\mathbf{x}$ & $\mathbf{x}$ & & $\mathbf{x}$ & \\
\hline $\begin{array}{l}\text { Noor Akmal } \\
\text { Adillah Ismail, Et } \\
\text { Al(2015) }\end{array}$ & $\mathbf{x}$ & $\mathbf{x}$ & & & \\
\hline TOTAL & 8 & 6 & 4 & 4 & 3 \\
\hline
\end{tabular}

B. The challenge and barrier without using Building Information Modelling

Takim, Harris, \& Nawawi (2013) mentioned the construction industry is yet to utilize BIM aggressively, even until now the construction sector in Malaysia is still facing the slow of progressive changes in the implementation of BIM The possible reasons may be difficulty implemented BIM and it will lead to the extra cost of the project, overall training and most of the designers are familiar with using AutoCAD. New technology adoption is the process that begins with technology consciousness and progresses through the different stages that end up with effective usages and appropriate. According to Wong, S. Y., \& Gray, J. (2019) when the construction players are using the new technology, some of the factors may affect their decisions on when to adopt the new technology. Normally, these decisions are based on their perceptions of using new technologies in digital communications. Therefore, further discussion for the challenge of without using BIM is needed.

The information from BIM is important for the management team to make an appropriate decision for future maintenance strategic. Without the use of 
BIM, the information is not accessible easily and the decision-maker cannot rely on the inaccurate data because the errors may be arising due to the uncertain information.

Choi \& Ryu (2015) mentioned that BIM can manage the projects starting from the pre-construction stage to the post-construction stage. During the process of the projects, it is not able to implement BIM in each of the stages and cannot manage all the activities in a construction project especially for the design project. Meanwhile, Yaakob, Ali \& Radzuan (2016) described that the design project is an essential activity in the construction industry as it is because for project scheduling and cost estimating can only be started after the completion of project design

Therefore, the application of BIM in the stage of project design is very important, if then the site analysis, project productivity, accuracy in preparing cost estimating and project scheduling cannot be achieved. Other than that, another ability of BIM is it can visualize the design and detect the clash during the design stage. Without using BIM, the request for information, incomplete specification and changes for design cannot be reduced during the construction stage. The potential for these issues cannot be minimized in the preconstruction stage. According to Thomson et al. (2019), for the existing modelling, it cannot increase the accuracy of existing documentation of condition. As in the scheduling stage of pre-construction, it unable the project manager and consultant to track the construction work sequence, track progress, equipment and materials against the timelines and logistics established. Without the application of BIM, it is unable the demonstration of the process that is included the traffic flows, entry and exit roads, site machinery and site material.

Therefore, with the use of BIM, it id enables the checking of work in actual time for allowing the faster flow of resources. Moreover, BIM can integrate the activities during the post-construction such as operation, maintenance and facilities management. Without the application of BIM in project design, it cannot help the facility managers to manage the facilities management by visualizing all the information in the $3 \mathrm{D}$ model and the information in the model cannot be easily shared to be used by the contractors. Therefore, without 
utilizing the BIM technology that cannot allow an effective and better plan for activities of the construction projects in which cannot overcome the potential errors in the design phase.

Banteli, \& Stevenson (2017) mentioned, delay and cost overrun are the most common risky and complex issues in construction projects. Without the application of BIM in project management, the detection of conflicts and clash analysis cannot be detected. In this condition, the time and construction cost also cannot be reduced. Other than that, the value for the money also cannot be improved if the BIM is not implemented in the construction

Mihindu, \& Arayici (2008) mentioned the most common cause of delay and cost overrun is due to inaccurate estimates, poor design and the mistake and error during the construction process. Therefore, with the application of BIM that can minimize the construction time and cost use in the projects. It also brings a great impact on project cost and time. Moreover, the introducing of the BIM offers beneficial opportunities to small of the construction companies by exploring and applying the BIM to their project. Without the application of BIM, small construction companies cannot increase staff productivity, efficiency and job satisfaction. Therefore, it will lead to the addition in the operating cost.

It is very challenging for modelling the $3 \mathrm{D}$ information of the built environment. However, the number of technology and technique are now in use such as GPS, EDM, building surveying applications and photogrammetric application as discussed by Chan, D. W., Olawumi, T. O., \& Ho, A. M. (2019). These technologies are not efficient and practical for existing structures in terms of accuracy, time and cost. Therefore, BIM should be practiced and explored to obtain the information for building management and use for the maintenance process in the existing building

Hence, without the application of BIM for the existing building, it cannot support all the phases of the project life-cycle. Azhar, S. (2011) stated the example, the model definition is from the conception to demolition by supporting the data over the complete facility lifecycle. If the employer requires the information for the environmental performance that can be 
compared with the design, information data or built by using the BIM. Other than that, the most important for use of BIM is it can integrate the information for the existing building. If without the application of BIM, the model for all the information in a single repository cannot be consistency precise and the data are not being able to access. Next, objects in the model have some predefined properties that allow for any number of the user that can be easily described by implement of the BIM such as the cost, date of last service and the manufacturer's product code. Table 3 tabulated the barriers in implementing BIM, while Table 4 tabulated analysis done by multiple authors regarding the challenges and barriers. 
Table 3. The challenge and barrier without using BIM

\begin{tabular}{|l|l|l|}
\hline NO & The Challenges of using BIM in the Construction Industry & Authors \\
\hline 1. & $\begin{array}{l}\text { The difficulty implemented the BIM and it will lead to extra cost } \\
\text { of the project, overall training and the most of the designer are } \\
\text { familiar in using of AutoCAD }\end{array}$ & $\begin{array}{l}\text { (Mohd Harris } \\
\text { MOhd Ismail, Et } \\
\text { Al, 2014) }\end{array}$ \\
\hline 2. & $\begin{array}{l}\text { The information is not accessible easily and the decision-maker } \\
\text { cannot rely on the inaccurate data }\end{array}$ & $\begin{array}{l}\text { (Adi Irfan Che } \\
\text { Ani, Et Al, 2015) }\end{array}$ \\
\hline 3. & $\begin{array}{l}\text { BIM are able to manage the projects starting from pre- } \\
\text { construction stage to post-construction stage }\end{array}$ & $\begin{array}{l}\text { (SUZILA BINTI } \\
\text { MOHD, 2015) }\end{array}$ \\
\hline 4. & $\begin{array}{l}\text { BIM is it can visualise the design and detect the clash during the } \\
\text { design stage }\end{array}$ & $\begin{array}{l}\text { Eastman and } \\
\text { Memon, 2012) }\end{array}$ \\
\hline 5. & $\begin{array}{l}\text { It unable the demonstration of the process that are included the } \\
\text { traffic flows, entry and exit roads, site machineries and site } \\
\text { material }\end{array}$ & $\begin{array}{l}\text { (Aryani Ahmad } \\
\text { Latiffi.Et Al. , } \\
2013)\end{array}$ \\
\hline 6. & $\begin{array}{l}\text { It cannot help the facility managers to manage the facilities } \\
\text { management by visualising all the information in the 3D model }\end{array}$ & $\begin{array}{l}\text { (Aryani Ahmad } \\
\text { Latiffi.Et Al. , } \\
\text { 2013) }\end{array}$ \\
\hline 7. & $\begin{array}{l}\text { The small construction companies cannot increase the staff } \\
\text { productivity, efficiency and job satisfaction }\end{array}$ & $\begin{array}{l}\text { (Aryani Ahmad } \\
\text { Latiffi.Et Al. , } \\
\text { (M. M. Tahir, } \\
\text { Haron, Et Al, } \\
\text { 2013) }\end{array}$ \\
\hline 9. & $\begin{array}{l}\text { Without the application of BIM for the existing building, it } \\
\text { cannot support all the phases of the project life-cycle }\end{array}$ & $\begin{array}{l}\text { (Adi Irfan Che } \\
\text { Ani, Et Al, 2015) }\end{array}$ \\
\hline
\end{tabular}


Table 4. Analysis by multiple authors about the challenges on using BIM

\begin{tabular}{|c|c|c|c|c|c|}
\hline CHALLENGES & $\begin{array}{l}\text { Cost } \\
\text { Overrun }\end{array}$ & $\begin{array}{l}\text { Delay in the } \\
\text { construction } \\
\text { project }\end{array}$ & $\begin{array}{l}\text { Occurrence } \\
\text { of the } \\
\text { dispute }\end{array}$ & $\begin{array}{l}\text { Cannot } \\
\text { detect the } \\
\text { design clash }\end{array}$ & $\begin{array}{l}\text { Unable to } \\
\text { detect the } \\
\text { potential } \\
\text { risk }\end{array}$ \\
\hline $\begin{array}{l}\text { Suzila Mohd and } \\
\text { Aryani Ahmad } \\
\text { Latiffi (2013) }\end{array}$ & $\mathrm{x}$ & $\mathrm{x}$ & $\mathrm{x}$ & $\mathrm{x}$ & \\
\hline $\begin{array}{l}\text { M M Mering, E } \\
\text { Aminudin, C S } \\
\text { Chai, R Zakaria, C. } \\
\text { S. Tan, Y Y Lee } \\
\text { and A A Redzuan } \\
\text { (2017) }\end{array}$ & & & & & $\mathrm{x}$ \\
\hline $\begin{array}{l}\text { Mohammed Btoush } \\
\text { and Haron Ahmad } \\
\text { Tarmizi (2017) }\end{array}$ & $\mathrm{x}$ & $\mathrm{x}$ & & & \\
\hline $\begin{array}{l}\text { Y Arayici, CO } \\
\text { Egbu and SP } \\
\text { Coated (2012) }\end{array}$ & & $\mathrm{x}$ & & & \\
\hline $\begin{array}{l}\text { A. Charehzehi, C. } \\
\text { Chai, A. Md. } \\
\text { Yusof, H.Y. Chong } \\
\text { and S.C. Loo } \\
\text { (2017) }\end{array}$ & $x$ & $\mathrm{x}$ & $\mathrm{x}$ & $\mathrm{x}$ & \\
\hline $\begin{array}{l}\text { Salman Azhar, } \\
\text { Malik Khalfan and } \\
\text { Tayyab Maqsood } \\
\text { (2015) }\end{array}$ & $\mathrm{x}$ & $\mathrm{x}$ & & $\mathrm{x}$ & \\
\hline TOTAL & 4 & 5 & 2 & 3 & 1 \\
\hline
\end{tabular}

C. The strategic planning being implemented within the next 5 years in Malaysia

According to Musa, Marshall-Ponting, Nifa \& Shahron (2018) with the advancing of BIM technology by many of the countries, Malaysia had recognized the importance of implementation of BIM in the construction project to localized and adapted the construction players. Due to the complexity of the construction process, this new technology to be adopted frequently, support and training by the construction players. Therefore, a welldocumented execution plan is required for successful strategy implementation in the construction industry. Puust, R., Witt, E. D., Lill, I., \& Liias, R. (2019) outlined 4 steps of processes is used to classify the priority initiatives which 
had been implemented to determine the execution plan and potential strategies in the construction process.

\section{Step 1: Global Benchmarking Through Literatures}

The global benchmarking focuses on four continents which is Singapore, Hong Kong, Australia, and the UK. A total of 26 initiatives had been determined through the literature search during the first step of research. All the initiatives are being recorded and marked for comparison with expert's opinions and local stakeholders in the next process.

Step 2: Engagement with local stakeholders and experts

This process involved the engagement of stakeholders, local authority and experts through structured interviews and workshops. All the initiatives are obtained from Step1 and Step2 are being grouped based on the similarity.

Step 3: Prioritizing the Initiatives

This process consists of an analysis of the initiatives of priority that using the prioritizing tools which is Ease of Implementation (EOI) and Impact (Imp) that used to prioritize the potential initiatives as for the predetermining factors. Step 4: Validation by the Expert panel

Through the means of a workshop, a total of 13 initiatives is brought toward to be validated by the expert panel. Other than that, the expert panel is selected from the contractors, government agencies, professional bodies, and academia. There are 12 experts attended the workshop that involved 1 from government agencies, 7 from professional bodies, 2 from contractors and 2 from academia. Summarised for the BIM initiatives is tabulated in Table 5.

\section{Conclusion}

Table 6 summarises the initiatives and activities in implementing the BIM. It was outlined based on the benefits and challenges in implementing BIM. There were 8 initiatives known in giving highest impact that needed to be focused within the next 5 years in implementing the BIM in Malaysia construction industry. It is because the implementation of BIM will bring longterm benefits to all construction parties in Malaysia. 
Table 5. Summarized for the BIM initiatives

\begin{tabular}{cl}
\hline CODING & INITIATIVES \\
\hline 1.01 & Establishment of National BIM Roadmap \\
\hline 1.02 & Incentives for software and training \\
\hline 1.03 & Collaboration of BIM activities among agencies \\
\hline 1.04 & BIM Standard and common practice \\
\hline 1.05 & Legal and insurance related to BIM implementation \\
\hline 1.06 & Awareness, training and education \\
\hline 1.07 & Building capability \& capacity of people \\
\hline 1.08 & Mandating BIM for public sector \\
\hline 1.09 & In-house proprietary BIM solution \\
\hline 1.10 & Product Information \& BIM libraries \\
\hline 1.11 & BIM Guidelines \\
\hline 1.12 & Digital Infrastructures Capability and vendor support \\
\hline 1.13 & Information Exchange platform for Level 2 BIM \\
\hline 1.14 & Compliance, Accreditation \& Certification \\
\hline 1.15 & Changing Procurements processes \\
\hline 1.16 & Business process Change \\
\hline 1.17 & Multi-disciplinary BIM education \\
\hline 1.18 & Special interest groups \\
\hline 1.19 & Research \& Development fund \\
\hline 1.20 & Forming BIM committee \\
\hline 1.21 & Establish BIM reference center \\
\hline 1.22 & Registration with international bodies (BuildingSMART \\
\hline 1.23 & International) \\
\hline 1.24 & Annual BIM award to recognise advance use of BIM \\
\hline & \\
\hline
\end{tabular}

Table 6. BIM initiatives and activities

\begin{tabular}{|c|c|c|c|}
\hline & INITIATIVES & & ACTIVITIES \\
\hline 1.01 & Establishment of National BIM Roadmap & 1.06 & Forming BIM committee \\
\hline 1.02 & Incentives for software and training & & TBD \\
\hline 1.07 & Building capability \& capacity of people & 1.01 & Awareness, training and education \\
\hline 1.08 & Mandating BIM for public sector & & TBD \\
\hline I.11 & BIM Guidelines & & TBD \\
\hline 1.14 & Compliance, Accreditation \& Certification & 1.04 & BIM Standard and common practice \\
\hline 1.19 & Research \& Development fund & & TBD \\
\hline & Establish BIM reference center & $\begin{array}{l}1.10 \\
1.22\end{array}$ & $\begin{array}{l}\text { Product Information \& BIM libraries } \\
\text { Registration with international bodies } \\
\text { (BuildingSMART International) }\end{array}$ \\
\hline
\end{tabular}




\section{Acknowledgement}

The authors would like to thank SEGi University for the opportunity and platform provided.

\section{References}

Takim, R., Harris, M., \& Nawawi, A. H. (2013). Building information modeling (BIM): A new paradigm for quality of life within architectural, engineering and construction (AEC) industry. Procedia - Social and Behavioral Sciences, 101, 23-32

Tahir, M. M., Haron, N. A., Alias, A. H., Al-Jumaa, A. T., Muhammad, I. B., \& Harun, A. N. (2017). Applications of building information model (BIM) in Malaysian construction industry. IOP Conference Series: Materials Science and Engineering, 291, 012009

Musa, S., Marshall-Ponting, A., Nifa, F. A., \& Shahron, S. A. (2018). Building information modeling (BIM) in Malaysian construction industry: Benefits and future challenges

Abulifa, A. A., Ahmad, R. K., Soh, A. C., Radzi, M. A., \& Hassan, M. K. (2017). Modelling and simulation of battery electric vehicle by using MATLAB-simulink. 2017 IEEE 15th Student Conference on Research and Development (SCOReD)

Ahmad Latiffi, A., Mohd, S., \& Brahim, J. (2014). Building information modeling (Bim) roles in the Malaysian construction industry. Proceedings of International StructuralEngineeringand Construction, 1(1)

Wong, S. Y., \& Gray, J. (2019). Barriers to implementing building information modelling (BIM) in the Malaysian construction industry. IOP Conference Series: Materials Science and Engineering, 495, 012002

Choi, J., \& Ryu, H. (2015). Application and effects analysis of BIM(Building information modeling) for construction management of a construction Field. Journal of the Korea Institute of Building Construction, 15(1), $115-121$

Yaakob, M., Ali, W. N., \& Radzuan, K. (2016). Identifying critical success factors (CSFs) of implementing building information modeling (BIM) in Malaysian construction industry 
Thomson, G., Lindahl, G., Shemery, A., Roupé, M., Hampson, K., \& Johansson, M. (2019). BIM related innovation in healthcare precinct design and facilities management. 10th Nordic Conference on Construction Economics and Organization, 455-462

Banteli, A., \& Stevenson, V. E. (2017). Building information modelling (Bim) as an enabler for whole-building embodied energy and carbon calculation in early-stage building design. Building Information Modelling (BIM) in Design, Construction and Operations II

Mihindu, S., \& Arayici, Y. (2008). Digital construction through BIM systems will drive the re-engineering of construction business practices. 2008 International Conference Visualisation

Chan, D. W., Olawumi, T. O., \& Ho, A. M. (2019). Critical success factors for building information modelling (BIM) implementation in Hong Kong. Engineering,

ConstructionandArchitecturalManagement, 26(9),1838-1854

Azhar, S. (2011). Building information modeling (BIM): Trends, benefits, risks, and challenges for the AEC industry. Leadership and Management in Engineering, 11(3),241-252.

Puust, R., Witt, E. D., Lill, I., \& Liias, R. (2019). Investigating the drop-out rate from a BIM for infrastructure course. Proceedings of the 2019 European Conference on Computing in Construction 